\title{
PERAN MODAL SOSIAL TERHADAP KESEJAHTERAAN PENGUSAHA SEKTOR INFORMAL (Kasus Pengusaha Sektor Informal di Pasar Jl. Dewi Sartika, Bogor)
}

\section{Role of Social Capital on Prospering Informal Sector Enterprise (Case of Street Vendors in street market Dewi Sartika, Bogor)}

\author{
Dedy Yahya Harahap ${ }^{1)}$, Ivanovich Agusta ${ }^{1)}$
}

\author{
${ }^{1)}$ Departemen Sains Komunikasi dan Pengembangan Masyarakat, Fakultas Ekologi Manusia, \\ Institut Pertanian Bogor, Darmaga Bogor 16680, Indonesia \\ E-mail: akuudedhy@gmail.com; iagusta@apps.ipb.ac.id
}

\begin{abstract}
Goal of the study was to test contribution social capital on migration, of the informal sector, social capital education entrepreneurs to improve informal sector entrepreneurs. The research conducts quantitative approach by survey methods and supported by qualitative data. The results showed assosiation between social capital and informal entrepreneur's welfare. Spearman rank test between social anf welfare showed -0.480. That indicated inverse relationship among them. Spearman rank test between social capital on imigration and welfare showed 0.723. That indicate positive relationship between them. Spearman rank test between social capital an education and welfare showed 1.000. That indicated fully positive relationship between them.
\end{abstract}

Keywords : Welfare, Social Capital, Informal Sector.

\begin{abstract}
ABSTRAK
Tujuan dalam penelitian ini adalah menguji kontribusi modal sosial pekerja pengusaha sektor informal, modal sosial migrasi sektor informal, modal sosial pendidikan pengusaha sektor informal dalam meningkatkan kesejahteraan pengusaha sektor informal. Penelitian ini menggunakan pendekatan kuantitatif dengan metode survey didukung dengan data kualitatif berupa wawancara mendalam, observasi. Hasil penelitian menunjukkan bahwa, peran modal sosial terhadap kesejahteraan berhubungan nyata. Uji kolerasi rank spearman menunjukkan bahwa hubungan pengusaha sektor informal dan kesejahteraan sebesar -0.480 dan nilai probabilitas sebesar 0.004. Hasil tersebut menunjukkan hubungan kuat namun berdifat negatif. Hubungan modal sosial migrasi pengusaha sektor informal dan kesejahteraan sebesar 0.723 dan nilai probabilitas sebesar 0.000 . Hasil tersebut menunjukkan hubungan yang kuat dan bersifat positif antara kedua variabel. Hubungan modal sosial pendidikan pengusaha sektor informal dan kesejahteraan sebesar 1.000 dan nilai probabiliti sebesar 1.000. Hasil tersebut menunjukkan hubungan yang kuat, bersifat positif antara kedua variabel.
\end{abstract}

Kata Kunci : Kesejahteraan, modal sosial, sektor informal.

\section{PENDAHULUAN}

Sektor informal telah dikenal sebagai fenomena alami di banyak negara berkembang termasuk negara Indonesia. Di Indonesia pekerja sektor informal merupakan angkatan kerja dominan dalam pemenuhan perekonomian masyarakat. Sektor informal menjadi alternatif lapangan usaha bagi masyarakat. Berdasarkan data Badan Pusat Statistik (2016), jumlah angkatan kerja diperkirakan sebesar 127.67 juta jiwa dengan komposisi pekerja formal 46.6 persen dan pekerja sektor informal 53.6 persen. Tingginya komposisi pekerja sektor informal, menjadikan sektor informal sebagai katup pengaman dalam mengahadapi masalah angkatan kerja masyarakat Indonesia. Adapun penyebab tingginya pertumbuhan ekonomi sektor informal di Indonesia karena karakteristik usaha sektor informal itu sendiri yaitu suatu kegiatan yang 
usahanya tidak terorganisir secara baik karena unit usaha muncul tanpa menggunakan fasilitas atau kelembagaan yang tersedia di sektor formal, unit usaha tidak mempunyai ijin usaha, memiliki pola kegiatan usaha tidak teratur baik dalam arti lokasi maupun jam kerja, unit usaha bergantiganti dari satu sub sektor ke sub sektor yang lain, memiliki teknologi yang masih tradisional, modal usaha yang relatif kecil, menjalankan usaha tidak memerlukan pendidikan formal karena sebagian besar keterampilan usaha diperoleh dari pengalaman sambil bekerja, menggunakan pekerja yang berasal dari keluarga sendiri serta hasil produksi atau jasa dalam usaha sektor informal terutama dikonsumsi masyarakat berpenghasilan menengah ke bawah (Magdalena 1991).

Sektor informal menjadi bagian penting dalam pertumbuhan ekonomi masyarakat terutama masyarakat miskin karena dapat menjadi sumber pendapatan untuk pemenuhan kebutuhan hidup, sehingga perlu bagi pemerintah untuk memperhatikan keberlangsungan ekonomi sektor informal sebagai pembangunan ekonomi bangsa. Penelitian Abidin (2010) juga dijelaskan bahwa modal sosial mempunyai kontribusi lebih besar dibandingkan modal fisik dalam mempengaruhi indeks keuntungan. Hal ini terjadi karena hubungan modal sosial mampu memberikan kemudahan bagi pekerja sektor informal dalam mengembangkan usahanya. Namun menurut Field (2010), modal sosial juga dapat mendorong ketimpangan terutama karena akses terhadap tipe jaringan yang berbeda terdistribusi secara tidak merata. Mereka yang memiliki hubungan terbanyak cenderung menggunakannya untuk mengejar kepentingan mereka.

Jalan Dewi Sartika Kota Bogor khususnya di pasar Jl. Dewi Sartika, Bogor merupakan salah satu tempat dimana pengusaha sektor informal tersebar luas, khususnya Pedagang Kaki Lima (PKL). Hal tersebut dapat dilihat dari banyaknya tenda-tenda, meja-meja, bahkan sekedar alas diletakkan di sisi jalan dan diletakkan sembarangan di badan jalan. Hal tersebut dikarenakan karakteristik Pengusaha yang memang memiliki ciri seperti unit usahanya tidak memiliki izin, memiliki pola usaha yang tidak teratur baik dalam arti lokasi dan jam bekerja, unit usaha yang tidak konsisten, memiliki teknologi yang masih tradisional tidak memerlukan pendidikan karena bergantung pada pengalaman kerja, sumberdaya pekerja keluarga, serta hasil produksi atau jasa di konsumsi oleh masyarakat berpenghasilan menengah kebawah.

Disamping itu sebagian dari banyak populasi pengusaha sektor informal yang ada di pasar Jl. Dewi Sartika, Bogor merupakan para pendatang dari berbagai wilayah yang ada di indonesia serta dengan latar belakang pendidikan yang berbeda-beda. Selain itu tujuan pengusaha sektor informal berpindah tempat dari tempat asalnya ke pasar Jl. Dewi Sartika, Bogor untuk berdagang, tidak lain karena ingin merubah nasib, dalam kata lain pengusaha sektor informal ingin mencapai tahap kesejahteraan. Oleh karena itu, dibutuhkan peran modal sosial dalam kesejahteraan pengusaha sektor informal. Berdasarkan latar belakang diatas, penelitian ini mengenai bagaimana peran modal sosial terhadap kesejahteraan pengusaha sektor informal.

Penduduk yang mulai beralih menuju sektor informal dari profesi lain disebabkan oleh beberapa faktor tertentu, yang paling utama yaitu faktor ekonomi. Pada umumnya untuk beralih menuju sektor informal karena sektor informal berbeda dengan pekerjaan yang ada pada sektor formal. Sektor informal cenderung tidak memiliki izin, waktu bekerja, dan lain sebagainya. Maka dari itu tidak sedikit penduduk yang beralih pada pekerjaan sektor informal. Penduduk yang mulai beralih ke sektor informal akan mengalami perubahan-perubahan dan penyesuaian dengan lingkungan yang dihadapinya. Perubahan yang terjadi dalam kehidupan masyarakat ini mencakup berbagai aspek termasuk aspek modal sosial. Di pasar Jl. Dewi Sartika, Bogor populasi dari pengusaha sektor informal terhitung cukup besar, maka dari itu peran modal sosial pengusaha sektor informal dibutuhkan dalam penyesuaian dengan lingkungan di pasar Jl. Dewi Sartika. Penyesuaian yang dilakukan juga akan berdampak pada kesejahteraan. Oleh sebab itu, penting untuk menganalisis bagaimana hubungan modal sosial pengusaha sektor informal terhadap kesejahteraan. 
Menurut Sethuraman (2000) pekerja sektor informal pada umumnya adalah para pendatang, berpendidikan rendah, minim keterampilan, dari kalangan masyarakat miskin. Indikator yang digunakan yaitu berpendidikan rendah, minim keterampilan, miskin/rentan. Di pasar J1. Dewi Sartika terhitung cukup tinggi populasi pedagang yang berasal dari daerah luar jawa barat, seperti dari Sumatera Utara, Sumatera Barat, Jawa Timur, Jawa Tengah, dan masih banyak lagi. Penduduk yang datang untuk berdagang di pasar J1. Dewi Sartika membutuhkan sebuah penyesuaian di lingkungan yang baru, maka dari itu dibutuhkan peran modal sosial dalam penyesuaian tersebut. Disamping itu tujuan para pedagang tersebut datang ke Jawa Barat khususnya di pasar Jl. Dewi Sartika Kota Bogor ini tidak lain untuk mengubah nasib, dengan kata lain mereka datang untuk mencapai kesejahteraan. Oleh sebab itu, penting untuk menganalisis bagaimana hubungan peran modal sosial migrasi terhadap kesejahteraan pengusaha sektor informal.

Pendidikan adalah segala pengalaman belajar yang berlangsung dalam lingkungan dan sepanjang hidup (long life education). pendidikan biasanya di tempuh dalam berbagai jenjang tingkatan, yaitu SD, SMP, SMA, S1, S2, S3. Pada saat menempuh jenjang pendidikan tersebut, lingkungan sekolah ataupun perkuliahan mencakup berbagai aspek termasuk aspek modal sosial. Menurut Sethuraman (2000) pekerja sektor informal pada umumnya adalah para pendatang, berpendidikan rendah, minim keterampilan, dari kalangan masyarakat miskin. Indikator yang digunakan yaitu berpendidikan rendah, minim keterampilan, miskin/rentan. salah satu karakteristik pengusaha sektor informal yaitu berpendidikan rendah, dimana kebanyakan pedagang menganggap hal terpenting dalam berdagang bukan hanya pendidikan saja, tetapi pengalaman. Begitu juga para pedagang di pasar Jl. Dewi Sartika yang memiliki latar belakang pendidikan yang berbeda-beda. Sedangkan tujuan pendidikan nasional adalah menghasilkan manusia dan masyarakat Indonesia yang demokratis-religius, berjiwa mandiri, bermartabat, menjujung tinggi harkat dan martabat kemanusiaan dan menekankan keunggulan sehingga tercapai kemajuan dan kemakmuran (Depdiknas 2000). Maka dari itu kunci dari kesejahteraan adalah pendidikan. Oleh sebab itu, penting untuk menganalisis bagaimana hubungan peran modal sosial pendidikan terhadap kesejahteraan pengusaha sektor informal.

\section{PENDEKATAN TEORITIS Modal Sosial}

Konsep modal sosial pertama kali diperkenalkan oleh L.J. Hanifan pada awal abad ke-20. Hanifan menyatakan bahwa modal sosial bukanlah modal dalam arti biasa seperti harta kekayaan atau uang, tetapi lebih mengandung arti kiasan, tetapi merupakan asset atau modal nyata yang penting dalam hidup bermasyarakat.

Bourdieu (1986) mendefinisikan modal sosial sebagai keseluruhan sumberdaya baik yang aktual maupun potensial yang terkait dengan kepemilikan jaringan hubungan kelembagaan yang tetap dengan didasarkan pada saling kenal dan saling mengakui. Kata lain, dengan menjadi anggota dari suatu kelompok orang akan memperoleh dukungan dari modal yang dimiliki secara kolektif. Selanjutnya ia mengatakan bahwa besarnya modal sosial yang dimiliki seorang anggota dari suatu kelompok tergantung pada seberapa jauh kuantitas maupun kualitas jaringan hubungan yang dapat diciptakannya, serta seberapa besar volume modal ekonomi, budaya dan sosial yang dimiliki oleh setiap orang yang ada dalam jaringan hubungannya.

Coleman (1988) dalam sebuah tulisan yang berjudul "Social Capital in the Creation of Human Capital" memperkenalkan modal sosial sebagai sarana konseptual untuk memahami orientasi teoritis tindakan sosial dengan mengaitkan komponen-komponen dari perspektif sosiologi dan ekonomi. Demikian ia menggunakan prinsip-prinsip dalam ilmu ekonomi untuk menganalisis proses sosial. Coleman (2008) mengartikan modal sosial ini sangat penting bagi komunitas karena (1) memberikan kemudahan dalam mengakses informasi bagi anggota komunitas; (2) menjadi media pembagian kekuasaan dalam komunitas; (3) mengembangkan solidaritas; (4) memungkinkan mobilisasi sumber daya komunitas; (5) memungkinkan pencapaian 
bersama; dan (6) membentuk perilaku kebersamaan dan berorganisasi komunitas.

Putnam (1993) mendefinisikan modal sosial sebagai bagian dari organisasi sosial, seperti kepercayaan, norma, dan jaringan, yang dapat meningkatkan efisiensi masyarakat dengan memfasilitasi tindakan-tindakan terkoordinasi. Putnam (1993) Dalam bukunya "Making Democracy Work: Civic Traditions in Modern Italy" mendefinisikan modal sosial sebagai 'features of social organisation, such as networks, norms, and trust, that facilitate coordination and co-operation for mutual benefit. Buku tersebut disimpulkan bahwa kinerja institusional di Italia utara relatif sukses dikarenakan adanya hubungan timbal balik antara pemerintah dengan masyarakat sipil. Penelitian itu ditunjukkan pula bahwa dukungan masyarakat sipil ditambah efektivitas institusi pemerintah daerah Italia utara memiliki tingkat kemakmuran yang lebih baik daripada pemerintah Italia wilayah selatan.

Modal sosial merupakan istilah berkaitan erat dengan kehidupan sehari-hari. Meskipun bagi sebagian orang istilah modal sosial masih dirasa asing dan baru dikembangkan pada awal abad ke-19, namun nyatanya modal sosial telah tumbuh dan berkembang sejak lama dalam kehidupan manusia. Banyak ahli yang mencoba mendefinisikan modal sosial ini. Diantaranya adalah James S. Coleman. Namun ia tidak mendefinisikan modal sosial secara eksplisit. Coleman (1988) dalam tulisannya mengemukakan bahwa modal sosial didefinisikan berdasarkan fungsinya. Lebih lanjut ia juga menyatakan bahwa modal sosial tidak hanya terdiri dari satu entitas, tetapi merupakan gabungan dari berbagai entitas yang memiliki dua elemen umum, yaitu aspek-aspek struktur sosial dan yang memfasilitasi tindakan oleh aktor atau pelaku yang ada dalam struktur tersebut. Tokoh berikutnya yang mencoba mendefinisikan modal sosial adalah Robert D. Putnam. Putnam (1995) menyatakan bahwa modal sosial merupakan fitur organisasi sosial yang terdiri dari jaringan, norma-norma, dan kepercayaan sosial yang memfasilitasi koordinasi dan kerjasama yang saling menguntungkan. Putnam (1995) menyatakan bahwa jaringan mendorong keterlibatan norma yang kuat, bersifat timbal balik dan mendorong munculnya kepercayaan sosial. Komponenkomponen ini kemudian banyak dijadikan sebagai rujukan oleh banyak peneliti dalam mengukur modal sosial yang ada di suatu wilayah tertentu. Hal ini bisa dilihat dari penelitian yang dilakukan oleh Triutami (2013), Alfiasari (2006), dan Rismawati (2010). Peneliti ini menggunakan jaringan, norma, dan kepercayaan, dalam mengukur dan menganalisis modal sosial yang ada di wilayah penelitian yang dilakukan oleh masing-masing peneliti.

Putnam (1993) yang juga menegaskan bahwa modal sosial seperti trust (rasa saling percaya), norm (hubungan saling timbal balik), dan jaringan kerja, memudahkan terjadinya koordinasi dan kerja sama untuk kemanfaatan bersama. (1) Kepercayaan (trust) ; Merupakan komponen mengenai bagaimana seseorang percaya kepada orang lain dalam suatu komunitas ataupun diluar komunitas. Hal ini berkaitan dengan bagaimana harapan-harapan yang muncul dari A yang mempercayai B dengan harapan bahwa harapan-harapan tersebut dapat terpenuhi. Sehingga kepercayaan bersifat timbal balik. Kaitannya dengan peningkatan usaha, kepercayaan sangat berpengaruh dalam bagaimana unit-unit yang ada dalam usaha tersebut bisa saling bekerja secara fungsional. Karena kepercayaan yang timbul dalam kelompok tertentu akan menimbulkan kepuasan yang akan berdampak positif pada kinerja. (2) Jejaring (network) ; Merupakan komponen mengenai banyaknya relasi-relasi yang terbentuk dari suatu komunitas di dalamnya maupun antar komunitas. Hal ini berkaitan dengan seberapa banyak seseorang yang dikenal dengan berbagai kelebihan dan kekurangan sehingga dapat dioptimalkan akses tersebut untuk berbagai kebutuhan. Selain itu, banyaknya jejaring memudahkan seseorang untuk meminta bantuan ketika sedang kesusahan karena semakin banyak jejaring, semakin banyak opsi yang muncul untuk diminta bantuannya. Hal ini menjadi penting dalam konteks pengembangan dan peningkatan usaha. Jejaring yang banyak memungkinkan pelaku usaha untuk memasarkan produknya dengan cara-cara yang variatif sesuai dengan banyaknya jejaring yang dimiliki. Selain 
itu jejaring yang dimiliki jika memiliki pengetahuan dan teknologi tertentu juga akan memudahkan efisiensi dalam peningkatan usaha. (3) Norma (norms) ; Merupakan komponen berisi peraturan-peraturan yang terdapat dalam suatu hubungan relasional, baik itu di masyarakat maupun di kelembagaan tertentu. Peraturan-peraturan yang dimaksud adalah peraturan tertulis dan tidak tertulis. Penekanan di komponen ini adalah mengenai ada tidaknya suatu norma dan bagaimana kepatuhan orangorang yang berada di dalam aturan tersebut berlaku. Semakin patuh anggota-anggota suatu komunitas tertentu, makan semakin baik modal sosialnya. Kaitannya dengan pengembangan usaha, norma merupakan suatu hal yang sangat penting terlebih jika suatu usaha memerlukan akselerasi dalam peningkatan usahanya. Contoh riil di masyarakat ketika pelaku usaha memerlukan pasokan bahan baku, terdapat suatu aturan dimana pelaku usaha boleh memasok bahan baku ke usahanya tanpa uang dengan berbagai persyaratan yang harus dipenuhi sebelumnya.

\section{Sektor Informal}

Istilah sektor informal pertama kali dilontarkan oleh Keith Hart (1971) dengan menggambarkan sektor informal sebagai bagian angkatan kerja kota yang berada diluar pasar tenaga terorganisasi (Mulyana 2011). Menurut Alma (2001) memberikan pengertian bahwa, istilah sektor informal biasanya digunakan untuk menunjukkan sejumlah kegiatan ekonomi yang berskala kecil. Tetapi akan menyesatkan bila disebutkan perusahaan berskala kecil, karena sektor informal dianggap sebagai suatu manifestasi situasi pertumbuhan kesempatan kerja di negara sedang berkembang, karena itu mereka yang memasuki kegiatan berskala kecil ini di kota, terutama bertujuan untuk mencari kesempatan kerja dan pendapatan daripada memperoleh keuntungan. Karena mereka yang terlibat dalam sektor ini pada umumnya miskin, berpendidikan sangat rendah, tidak terampil dan kebanyakan para migran, jelaslah bahwa mreka bukanlah kapitalis yang mencari investasi yang menguntungkan dan juga bukan pengusaha seperti yang dikenal pada umumnya.
Menurut Sethuraman yang dikutip Muchdarsyah Sinungan (1988) mendefinisikan sektor informal secara umum adalah sektor informal terdiri dari unit usaha beskala kecil yang memproduksi, mendistribusi barang dan jasa dengan tujuan pokok menciptakan kesempatan kerja dan pendapatan bagi dirinya masing-masing serta dalam ushanya itu sangat dibatasi oleh faktor modal maupun keterampilan. Menurut Bremen yang dikutip Rusli Ramli (1985) menyatakan, bahwa sektor informal merupakan suatu pekerjaan yang umumnya padat karya, kurang memperoleh dukungan dan pengakuan dari pemerintah juga kurang terorganisir dengan baik. Sedangkan menurut Hadionoto (1988) yang menyatakan bahwa pilihan sektor informal adalah suatu jawaban atas rendahnya pendidikan dan keterampilan yang dimiliki oleh anak-anak jalanan. Investasi yang diperlukan untuk sektor ini relatif rendah serta tidak memerlukan persyaratan kemampuan atau keterampilan khusus.

Penggunaan istilah formal dan informal pada dasarnya untuk menggambarkan sifat dualistik sistem ekonomi perkotaan. Sifat dualistik sistem ekonomi perkotaan di banyak negara berkembang telah diakui sejak tahun 1950-an oleh para peneliti, seperti (Boeke 1953), (Geertz 1963), (Hart 1970), (ILO 1972), (McGee 1973), dan (Santos 1979). (Boeke 1953) di dalam studinya tentang sistem ekonomi di Indonesia menggunakan terminologi ekonomi prekapitalis (precapitalistic economy) dan ekonomi kapitalis (capitalistic economy). Ekonomi prekapitalis ditenggarai (ditandai) oleh usaha individual dengan dukungan modal yang kecil, tergantung pada unit lokal, belum menggunakan alat-alat mekanik, dan sistem transport dan jaringan yang masih tradisional. Sebaliknya sistem kapitalis ditandai oleh sifat usaha yang telah terorganisir dan didukung oleh modal yang besar, produksi bersifat massal, menggunakan teknologi yang tinggi, dan sistem transport yang modern.

\section{Migrasi}

Migrasi merupakan salah satu dari komponen demografi yang juga mempengaruhi dinamika penduduk disamping fertilitas dan mortalitas. Para dikenal dengan teori LFR (Lewis-FeiRannis) menyatakan bahwa pada perpindahan 
penduduk pada dasarnya terjadi karena adanya perbedaan antara sektor kota yang modern dan sektor desa yang tradisional (Subri 2006).

Perserikatan Bangsa-Bangsa merumuskan bahwa migrasi penduduk sebagai suatu perpindahan tempat tinggal dari suatu unit administrasi ke unit administrasi yang lain United Nations (1970), Gould dan Prothero (1975) juga menekankan unsur perpindahan tempat tinggal. Namun menurut mereka, walaupun seseorang telah secara resmi pindah tempat, tetapi apabila ada niat sebelumnya untuk kembali ke tempat semula, maka harus dianggap sebagai mobilitas sirkuler, bukan sebagai migrasi

Menurut Tjiptoherijanto (2000) migrasi merupakan perpindahan orang dari daerah asal ke daerah tujuan. Keputusan migrasi didasarkan pada perbandingan untung rugi yang berkaitan dengan kedua daerah tersebut. Tujuan utama migrasi adalah meningkatkan taraf hidup migran dan keluarganya, sehingga umumnya mereka mencari pekerjaan yang dapat memberikan pendapatan dan status sosial yang lebih tinggi di daerah tujuan.

Definisi senada juga diungkapkan oleh Martin (2003), dimana migrasi adalah perpindahan penduduk dari satu daerah ke daerah lain, yang terjadi karena adanya perbedaan kondisi kedua daerah tersebut. Menurut Martin, perbedaan terbesar yang mendorong terjadinya migrasi adalah kondisi ekonomi dan non ekonomi. Berdasarkan pengelompokannya, maka faktor yang mendorong migran untuk migrasi dibedakan dalam tiga kategori, yaitu faktor demand pull, supply push dan network. Faktor demand pull terjadi jika ada permintaan tenaga kerja dari daerah tujuan, seperti tenaga kerja Meksiko yang direkrut untuk bekerja pada sektor pertanian di Amerika. Faktor supply push terjadi jika tenaga kerja sudah tidak mungkin lagi memperoleh pekerjaan di daerahnya sendiri, sehingga mendorong mereka untuk migrasi ke daerah lain. Network factor merupakan faktor yang dapat memberi informasi bagi migran dalam mengambil keputusan untuk migrasi.

Arus migrasi desa-kota yang cukup besar tidak semuanya terserap disektor industri modern dikota, karena keterbatasan sektor industri modern dan tidak semua migran memiliki skill atau kemampuan untuk masuk kesektor industri modern tersebut. Hal ini mengakibatkan para migran yang tidak dapat masuk kesektor industri modern lebih memilih sektor informal yang relatif mudah untuk dimasuki. Agar tetap dapat bertahan hidup (survive), para migran yang tinggal dikota melakukan aktifitas-aktifitas informal (baik yang sah dan tidak sah) sebagai sumber mata pencaharian mereka. Hal tersebut dilakukan dengan pertimbangan daripada menjadi pengangguran yang tidak memiliki penghasilan atau memiliki penghasilan tetapi rendah dan tidak tetap.

Konteks yang lebih luas, meningkatnya arus migrasi dapat mempengaruhi terjadinya perubahan komposisi penduduk di daerah yang terkait dan juga mempengaruhi pola komunikasi baik individu maupun kolektif dalam komunitas yang berbeda. Ini berarti dalam intensitas yang tinggi migarsi dapat memberikan pengaruh modernisasi pada daerah tujuan migrasi

Lebih spesifik lagi, pada mulanya aktivitas ini dianggap sebagai suatu proses kolonialisasi, baik yang dilakukan untuk kepentingan ekonomi maupun politik. Selain itu ada dua dimensi penting dalam penelahan migrasi ini yaitu dimensi waktu dan dimensi daerah. Dimensi waktu menurut BPS batasannya adalah menetap selama 6 bulan didaerah migran tersebut. Sedangkan untuk dimensi daerah batasannya unit wilayah dibagi dalam beberapa provinsi menurut (BPS). Migrasi ini juga dijadikan salah satu alternatif pemerintah dalam pemerataan jumlah penduduk dan mengurangi angka pengangguran. Terbukti dengan peningkatan jumlah migran dari tahun ketahun yang sangat pesat.

\section{Pendidikan}

Menurut Fuad (2005) Pendidikan adalah aktivitas dan usaha manusia untuk meningkatkan kepribadiannya dengan jalan membina potensi potensi pribadinya, yaitu rohani (pikir, karsa, rasa, cipta dan budi nurani). Pendididkan juga berarti lembaga yang bertanggungjawab menetapkan cita - cita (tujuan) pendidikan, isi, sistem dan organisasi pendidikan Lembaga - 
lembaga ini meliputi keluarga, sekolah dan masyarakat.

Driyarkara mengatakan bahwa pendidikan adalah upaya memanusiakan manusia muda. Pengangkatan manusia ke taraf insani itulah yang disebut mendidik. Pendidikan adalah memberi kita perbekalan yang tidak ada pada masa anak-anak, akan tetapi kita membutuhkannya pada waktu dewasa (Abu 2003).

Undang-undang Sistem Pendidikan Nasional (SISDIKNAS) No 20 tahun 2003, menyebutkan bahwa pendidikan adalah usaha sadar dan terencana untuk mewujudkan suasana belajar dan proses pembelajaran agar peserta didik secara aktif mengembangkan potensipotensi dirinya untuk memiliki kekuatan spiritual keagamaan, pengendalian diri, kepribadian, kecerdasan, akhlak mulia, serta keterampilan yang diperlukan dirinya, masyarakat, bangsa dan negara (Undang-undang No. 20 Tahun 2003: 3).

Bratanata dkk. mengartikan pendidikan sebagai usaha yang sengaja diadakan baik langsung maupun dengan cara tidak langsung untuk membantu anak dalam perkembangannya untuk mencapai kedewasaannya (Ahmadi dan Uhbiyati 2007). Sedangkan John Dewey mendefinisikan pendidikan sebagai proses pembentukan kecakapan-kecakapan fondamental secara intelektual dan emosional kearah alam dan sesama manusia.

Pendidikan, seperti sifat sasarannya yaitu manusia, mengandung banyak aspek dan sifatnya sangat kompleks. Sebagai proses transformasi budaya, pendidikan diartikan sebagai kegiatan pewarisan budaya dari generasi satu ke genari yang lain. Sebagai proses pembentukan pribadi, pendidikan diartikan sebagai suatu kegiatan yang sistematis dan sistemik terarah kepada terbentuknya kepribadian peserta didik (Tirtarahardja et al. 2005).

Proses pembentukan pribadi meliputi dua sasaran yaitu pembentukan pribadi bagi mereka yang belum dewasa oleh mereka yang dewasa, dan bagi yang sudah dewasa atas usaha sendiri. Yang terakhir ini disebut pendidikan diri sendiri (self vorming). Kedua-duanya bersifat alamiah dan menjadi keharusan. Bayi yang baru lahir kepribadiannya belum terbentuk, belum mempunyai warna dan corak kepribadian yang tertentu. Ia baru merupakan individu, belum suatu pribadi. Untuk menjadi suatu pribadi perlu mandapat bimbingan, latihan-latihan, dan pengalaman melalui bergaul dengan lingkungannya, khususnya dengan lingkungan pendidikan (Tirtarahardja et al. 2005).

Bagi mereka yang sudah dewasa tetap dituntut adanya pengembangan diri agar kualitas kepribadian meningkat serempak dengan meningkatnya tantangan hidup yang selalu berubah. Dalam hubungan ini dikenal apa yang disebut pendidikan sepanjang hidup. Pembentukan pribadi mencakup pembentukan cipta, rasa, dan karsa (kognitif, afektif, dan psikomotor) yang sejalan dengan pengembangan fisik (Tirtarahardja et al. 2005).

\section{Kesejahteraan}

Menurut Fahrudin (2012), kesejahteraan sosial diartikan sebagai suatu kondisi dimana orang dapat memenuhi kebutuhannya baik dalam kebutuhan sandang, perumahan, pangan, kesehatan, dan dapat berelasi dengan lingkungannya secara baik untuk meningkatkan taraf hidup yang memuaskan. Suharto (2005), kesejahteraan sosial mencakup tiga konsepsi, yaitu: pertama, kondisi kehidupan atau keadaan sejahtera yaitu terpenuhinya kebutuhan jasmaniah, rohaniah, dan sosial.Kedua institusi, arena atau bidang kegiatan yang melibatkan lembaga kesejahteraan sosial dan berbagai profesi kemanusiaan yang menyelenggarakan usaha kesejahteraan sosial dan pelayanan sosial. ketiga aktivitas, yakni kegiatan-kegiatan atau usaha yang terorganisir untuk mencapai kondisi sejahtera.

Biro Pusat Statistik Indonesia (2000) menerangkan bahwa guna melihat tingkat kesejahteraan rumah tangga suatu wilayah ada beberapa indikator yang dapat dijadikan ukuruan, antara lain adalah: (1) Tingkat pendapatan keluarga; (2) Komposisi pengeluaran rumah tangga dengan membandingkan pengeluaran untuk pangan dengan non-pangan; (3) Tingkat pendidikan keluarga; (4) Tingkat 
kesehatan keluarga; (5) Kondisi perumahan serta fasilitas yang dimiliki dalam rumah tangga.

Stiglitz (2011) mengemukakan bahwa untuk mendefenisikan kesejahteraan, rumusan multidimensi harus digunakan. Dimensi-dimensi tersebut meliputi standar hidup material (pendapatan, konsumsi, dan kekayaan), kesehatan, pendidikan, aktivitas individu termasuk bekerja, suara politik, dan tata pemerintahan, hubungan dan kekerabatan sosial, lingkungan hidup (kondisi masa kini dan masa depan), baik yang bersifat ekonomi maupun fisik. semua dimensi ini menunjukkan kualitas hidup masyarakat dan untuk mengukurnya diperlukan data objektif dan subjektif.

Perumusan konsep kesejahteraan oleh Biro Pusat Statistik (BPS) dan Badan Koordinasi Keluarga Berencana Nasional (BKKBN) mengatakan bahwa keluarga yang dikatakan sejahtera apabila memenuhi kriteria berikut : (1) Keluarga yang dapat memenuhi kebutuhan anggotanya, baik kebutuhan sandang, pangan, perumahan, sosial maupun agama ; (2) Keluarga yang mempunyai keseimbangan antara penghasilan keluarga dan jumlah anggota keluarga ; (3) keluarga yang dapat memenuhi kebutuhan kesehatan anggota keluarga, kehidupan bersama dengan masyarakat sekitar, beribadah khusuk di samping kebutuhan pokok. Kesejahteraan pada intinya mencakup tiga konsepsi, yaitu: (1) Kondisi kehidupan atau keadaan sejahtera, yakni terpenuhinya kebutuhankebutuhan jasmaniah, rohaniah, dan sosial. (2) Institusi, arena atau bidang kegiatan yang melibatkan lembaga kesejahteraan sosial dan berbagai profesi kemanusiaan yang menyelenggarakan usaha kesejahteraan sosial dan pelayanan sosial. (3) Aktivitas, yakni suatu kegiatan-kegiatan atau usaha yang terorganisir untuk mencapai sejahtera.

konsep lain dari kesejahteraan yang melebihi konsep kemiskinan (poverty), baik diukur melalui dimensi moneter maupun non-moneter. Contohnya seperti ketimpangan. Ketimpangan menitikberatkan pada distribusi dari variabel terukur (misalnya pendapatan dan pengeluaran) terhadap seluruh penduduk. Hal ini didasarkan pada asumsi bahwa posisi relatif dari individu rumah tangga dalam masyarakat merupakan aspek penting dari kesejahteraan mereka.
Adapun usaha untuk meningkatkan kualitas hidup manusia secara menyeluruh mencakup: (1) Peningkatan taraf hidup, melalui seperangkat pelayanan sosial dan jaminan sosial segenap lapisan masyarakat, terutama kelompokkelompok masyarakat yang kurang beruntung dan rentan yang sangat memerlukan perlindungan sosial. (2) Peningkatan keberdayaan melalui penetapan sistem dan kelembagaan ekonomi, sosial, dan politik yang menjunjung harga diri dan martabat kemanusiaan. (3) Penyempurnaan kebebasan melalui perluasan aksebilitas dan pilihan-pilihan kesempatan sesuai dengan aspirasi, kemampuan dan standar kemanusiaan.

Menurut HAM, maka definisi kesejahteraan kurang lebih berbunyi bahwa setiap laki laki ataupun perempuan, pemuda dan anak kecil memiliki hak untuk hidup layak baik dari segi kesehatan, makanan, minuman, perumahan, dan jasa sosial, jika tidak maka hal tersebut telah melanggar HAM.

\section{Kerangka Pemikiran}

Pasar pasar Jl. Dewi Sartika merupakan salah satu tempat dimana kenbanyakan pengusaha sektor informal berdagang. Hal tersebut ditandai oleh banyaknya aktivitas bertransaksi jual beli yang dilakukan oleh konsumen dan pedagang. Lingkungan pasar J1. Dewi Sartika memiliki berbagai cakupan aspek termasuk aspek modal sosial. Modal sosial sebagai salah-satu komponen yang tumbuh dan berkembang dalam masyarakat memegang peranan penting dalam menjamin keberlangsungan sistem yang ada dalam masyarakat. Modal sosial dibentuk oleh beberapa unsur atau elemen yaitu kepercayaan, jaringan, serta nilai dan norma.

Putnam (1993) mengatakan bahwa modal sosial seperti trust (rasa saling percaya), norm (hubungan saling timbal balik), dan jaringan kerja, memudahkan terjadinya koordinasi dan kerja sama untuk kemanfaatan bersama. Setiap induvidu pengusaha sektor informal memiliki unsur atau elemen modal sosial didalam dirinya, unsur atau elemen ini kemudian akan berhubungan dengan kesejahteraan.

Populasi dari pengusaha sektor informal di pasar Jl. Dewi Sartika terhitung cukup tinggi, hal 
tersebut dapat dilihat dari banyaknya pedagang yang berbaris di bahu jalan sepanjang pasar. Kebanyakan dari populasi pengusaha sektor informal tersebut, adalah para migrasi dari wilayah luar Jawa Barat, Seperti dari Sumatera Utara, Sumatera Barat, Jawa Tengah, dan masih banyak lagi. Perubahan-perubahan tempat berdagang yang terjadi membutuhkan sebuah penyesuaian lingkungan. Perubahan yang terjadi dalam kehidupan pengusaha sektor informal yang bermigrasi membutuhkan peran modal sosial untuk dapat menyesuaikan diri dalam lingkungan pasar yang baru. Modal sosial pengusaha sektor informal tersebut berhubungan dengan kesejahteraan.

Aspek modal sosial pendidikan pengusaha sektor informal juga dibutuhkan dalam berdagang, karena pasalnya ilmu yang didapat semasa sekolah berguna didalam ruang lingkup perdagangan, baik dalam membaca dan menulis, berhitung, interaksi, sampai pada pendidikan karakter penting dalam berdagang. Dalam hal ini, modal sosial pendidikan pengusaha sektor informal berhubungan dengan kesejahteraan.

Karakteristik pekerja sektor informal menurut Sethuraman (2000) pekerja sektor informal pada umumnya adalah para pendatang, berpendidikan rendah, minim keterampilan, dari kalangan masyarakat miskin. Dalam hal ini indikator yang digunakan yaitu tingkat perpindahan/migrasi dan tingkat pendidikan variabel ini diukur dengan menggunakan data kualitatif.

Tingkat modal sosial pekerja pengusaha sektor informal, modal sosial migrasi pengusaha sektor informal, modal sosial pendidikan sektor informal yang memiliki indokator tingkat kepercayaan (trus), tingkat norma/nilai (norm), tingkat jaringan (network) yang diduga memiliki hubungan dengan tingkat kesejahteraan yang memiliki indikator tingkat pendapatan dan tingkat pengeluaran. Variabel ini diukur dengan menggunakan data kuantitatif.

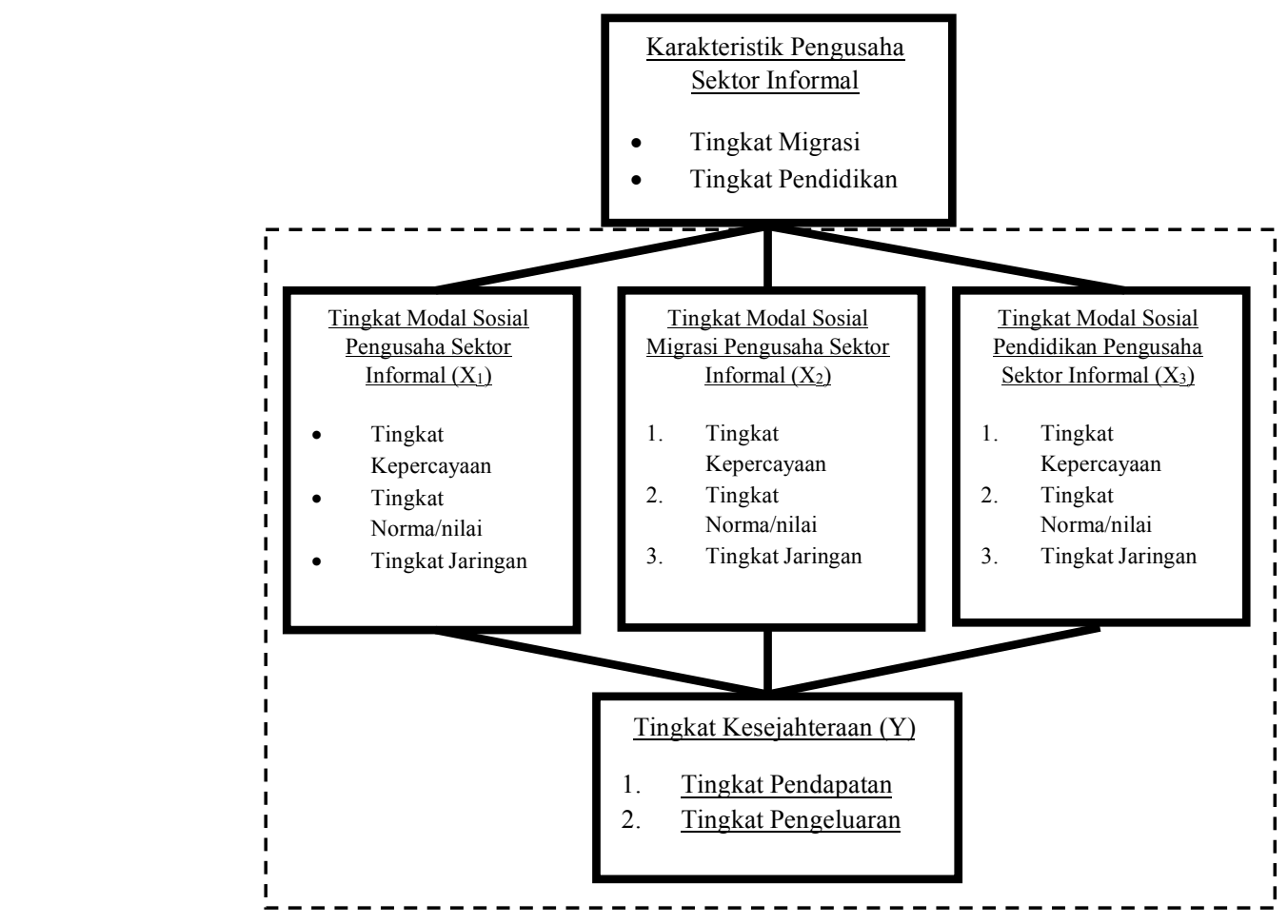

Keterangan :

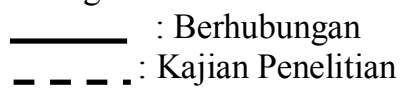




\section{Hipotesis}

Berdasarkan kerangka pemikiran diatas, maka hipotesis penelitian yang muncul adalah:

1. Diduga terdapat hubungan modal sosial terhadap tingkat kesejahteraan pengusaha sektor informal.

2. Diduga terdapat hubungan modal sosial migrasi terhadap tingkat kesejahteraan pengusaha sektor informal.

3. Diduga terdapat hubungan modal sosial pendidikan terhadap tingkat kesejahteraan pengusaha sektor informal.

\section{PENDEKATAN LAPANG}

Penelitian ini menggunakan metode penelitian kuantitatif dengan menggunakan pendekatan survei dan dikuatkan data kualitatif. Penelitian kuantitatif dilakukan dengan menggunakan survei melalui instrumen kuesioner yang diberikan kepada responden dengan unit analisis induvidu. Metode kuantitatif untuk menjawab pertanyaan peran modal sosial yang terdapat di pasar Jl. Dewi Sartika. Penelitian ini juga bersifat eksplanatori karena menjelaskan hubungan antar variabel melalui pengujian hipotesa (Singarimbun dan Effendi 1989). Sebelum ke lokasi penelitian, 10 kuesioner akan dilaksanakan uji coba terlebih dahulu sehingga peneliti dapat membuat sejauh mana suatu alat ukur dapat dipercaya atau tidak diandalkan apabila digunakan dua kali untuk mengukur gejala yang sama dan hasil pengukuran yang diperoleh relatif konsisten (Singarimbun dan Effendi, 1989).

Sebelum melakukan penelitian, 10 kuesioner akan dilakukan uji coba terlebih dahulu sehingga penelitian penelitian dapat melihat sejauhmana validitas dan reliabilitas kuesioner yang telah dibuat. Uji validitas dilakukan untuk menunjukkan sejauh mana alat pengukuran yang dilakukan sesuai dengan mengukur apa yang ingin diukur, sedangkan uji reliabilitas digunakan untuk menunjukkan sejauh mana suatu alat ukur dapat dipercaya atau dapat diandalkan apabila digunakan lebih dari satu kali untuk mengukur gejala yang sama dan hasil pengukuran yang diperoleh relatif konsisten (Singarimbun dan Effendi, 1989)

Lokasi penelitian dilaksanakan di lokasi prioritas sektor informal (Pedagang Kaki Lima) di kota Bogor, sebagaimana lokasi yang terletak di wilayah pasar Jl. Dewi Sartika tersebut, populasi dari pengusaha sektor informal (Pedagang Kaki Lima) terhitung cukup banyak. Sehingga dapat dilakukan sebuah penelitian. Lokasi tersebut dipilih karena alasan pasar tersebut merupakan salah satu kawasan jantung aktivitas Kota Bogor yang ramai dikunjungi masyarakat dalam belanja memenuhi kebutuhan sehari-hari. Pasar Jl. Dewi Sartika juga menjadi salah satu pusat aktivitas pedagang kaki lima. Hal ini disebabkan oleh lokasi pasar yang startegis, selain berada dekat dengan Stasiun Bogor dan juga jalur beberapa angkutan kota yang melintasi jalan disekitar pasar. Disamping itu juga karena banyaknya populasi pedagang kaki lima di pasar Jl. Dewi Sartika kota Bogor yang bermigrasi dari tempat tinggal asal ke kota bogor khususnya pasar $\mathrm{Jl}$. Dewi Sartika untuk berdagang.

Data yang digunakan dalam penelitian ini adalah data primer dan data sekunder. Data primer adalah data yang diperoleh hasil pengukuran metode kuantitatif yaitu pengisian kuisioner oleh responden terpilih. Data kualitatif dari responden maupun informan diperoleh melalui wawancara mendalam. Data sekunder diperoleh dari instansi terkait yaitu kantor Koperasi dan UMKM kota Bogor informasi, kantor pasar di pasar J1. Dewi Sartika maupun literatur-literatur yang mendukung topik penelitian. Data primer diperoleh dari pengamatan langsung di lapangan mengenai kondisi riil pengusaha sektor informal (Pedagang Kaki Lima) dan hasil pengisian kuesioner dari responden penelitian. Data primer yang digunakan berupa pemberian kuesioner kepada subyek penelitian dengan wawancara secara intensif dan mendalam (in-depth interview).

Data yang diperoleh dari peneliti ini berupa data kuantitatif dan data kualitatif. Data kuantitatif diperoleh melalui kuisioner yang akan diisi oleh 
responden yang kemudian akan disajikan ke dalam tabel frekuensi. Pengolahan data dilakukan dengan menggunakan aplikasi Microsoft Excell 2016 dan statistical for social science (SPSS) 22.0 for Windows.

Penelitian ini menggunakan sumber data dari responden dan informan melalui metode sensus dan wawancara mendalam. Responden merupakan pihak yang memberikan keterangan diri dan kegiatan yang dilaksanakannya, sedangkan informan merupakan pihak yang memberikan keterangan tentang pihak lain dan lingkungannya. Unit analisis penelitian ini adalah individu yang menjadi pedagang kaki lima di pasar Jl. Dewi Sartika, Bogor. Responden dalam penelitian ini adalah pengusaha sektor informal (Pedagang Kaki Lima) di pasar Jl. Dewi Sartika. Responden diwawancarai sesuai dengan kuesioner yang telah dibuat dan jawabannya dianggap dapat mewakili kondisi dirinya sebagai salah satu dari pengusaha sektor informal (Pedagang Kaki Lima) di pasar Jl. Dewi Sartika.

Teknik pengambilan sampel dalam penelitian ini yaitu probability sampling dengan metode simple random sampling. alasan pemeilihan teknik ini adalah populasi penelitian yang bersifat homogen dan keadaan populasi tidak tersebar secara geografis sehingga responden penelitian dapat dipilih secara acak untuk memudahkan proses penelitian dan pengumpulan data. Dari jumlah populasi yang berjumlah 50 orang, sampel yang akan diambil yaitu sebanyak 30 responden. Pemilihan informan dilakukan secara sengaja (purposive).

\section{HASIL DAN PEMBAHASAN}

\section{Hubungan Modal Sosial Pengusaha Sektor Informal dan Kesejahteraan}

Hubungan tingkat modal sosial pengusaha sektor informal lebih tinggi dari pada tingkat kesejahteraan rendah. Hal tersebut terlihat pada tingkat modal sosial pekerja sektor informal yang tinggi sebesar 13.3 persen, dan pada tingkat kesejahteraan rendah, sebesar 0 persen. Disebabkan karena tingginya solidaritas para pedagang di Jl. Dewi Sartika dikarenakan berasal dari tanah kelahiran yang sama, sehingga modal sosial pada pedagang di Jl. Dewi Sartika tinggi, tetapi untuk masalah pendapatan dan pengeluaran, para pedagang di Jl. Dewi Sartika lebih memilih untuk mengolahnya sendirisendiri tanpa ada campur tangan pedagang lain, dengan kata lain, pendapatan dan pengeluaran para pedagang, mereka lebih memilih untuk mengolahnya sendiri.

Tabel 1 Hubungan modal sosial pekerja sektor informal dengan kesejahteraan

\begin{tabular}{ccccccccc}
\hline Modal & \multicolumn{5}{c}{ Kesejahteraan } & Total \\
\cline { 2 - 7 } $\begin{array}{c}\text { sosial } \\
\text { pekerja } \\
\text { sektor }\end{array}$ & Rendah & \multicolumn{3}{c}{ Sedang } & Tinggi & & \\
\cline { 2 - 8 } informal & $\mathbf{n}$ & $\mathbf{\%}$ & $\mathbf{n}$ & $\mathbf{\%}$ & $\mathbf{n}$ & $\mathbf{\%}$ & $\mathbf{n}$ & $\mathbf{\%}$ \\
\hline Rendah & 0 & 0 & 0 & 0 & 0 & 0 & 0 & 100 \\
Sedang & 0 & 0 & 0 & 0 & 1 & 100 & 1 & 100 \\
Tinggi & 4 & 13.8 & 25 & 86.2 & 0 & 0 & 29 & 100 \\
\hline Total & 4 & 13.3 & 25 & 83.3 & 1 & 3.3 & 30 & 100 \\
\hline
\end{tabular}

\section{Hubungan Modal Sosial Migrasi dan Kesjahteraan}

Hubungan tingkat modal sosial migrasi sektor informal terhadap kesejahteraan terlihat samasama pada tingkat sedang. Terlihat pada tingkat modal sosial migrasi sektor informal dan kesejahteraan memiliki jumlah dan persentase yang sama sebesar 95.8 persen. Hal tersebut dikarenakan jumlah pedagang yang bermigrasi cukup tinggi sehingga persaingan pasar juga cukup ketat, walaupun para pedagang kaki lima di Jl. Dewi Sartika berasal dari tanah yang sama yaitu sumatera barat, tetapi masalah mengkais rezeki mereka juga saling bersaing.

Tabel 2 Hubungan modal sosial migrasi pekerja sektor informal dengan kesejahteraan

\begin{tabular}{|c|c|c|c|c|c|c|c|c|}
\hline \multirow{3}{*}{$\begin{array}{l}\text { Modal } \\
\text { sosial } \\
\text { migrasi } \\
\text { sektor } \\
\text { informal }\end{array}$} & \multicolumn{6}{|c|}{ Kesejahteraan } & \multirow{2}{*}{\multicolumn{2}{|c|}{ Total }} \\
\hline & \multicolumn{2}{|c|}{ Rendah } & \multicolumn{2}{|c|}{ Sedang } & \multicolumn{2}{|c|}{ Tinggi } & & \\
\hline & $\mathbf{n}$ & $\%$ & $\mathbf{n}$ & $\%$ & $\mathbf{n}$ & $\%$ & $\mathbf{n}$ & $\%$ \\
\hline Rendah & 3 & 75 & 1 & 25 & 0 & 0 & 4 & 100 \\
\hline Sedang & 1 & 4.2 & 23 & 95.8 & 0 & 0 & 24 & 100 \\
\hline Tinggi & 0 & 0 & 1 & 50 & 1 & 50 & 2 & 100 \\
\hline Total & 4 & 13.3 & 25 & 83.3 & 1 & 3.3 & 30 & 100 \\
\hline
\end{tabular}

Hubungan Modal Sosial Pendidikan dan Kesejahteraan 
Hubungan tingkat modal sosial pendidikan sektor informal terhadap kesejahteraan terlihat sama-sama pada tingkat sedang. Terlihat pada tingkat modal sosial pendidikan sektor informal dan kesejahteraan memiliki jumlah dan persentase yang sama sebesar 83.3 persen. Hal tersebut dikarenakan pendidikan para pedagang di Jl. Dewi Sartika tidak begitu tinggi, mereka hanya mengetahui jenjang pendidikan yang sesuai dengan tingkatan pendidikan untuk berdagang, pendidikan para pedagang di $\mathrm{Jl}$. Dewi Sartika sendiri tidak ada yang sampai pendidikan tinggi, rata-rata SMP sampai SMA. Para pedagang di Jl. Dewi Sartika lebih percaya dengan keyakinan yang di berikan oleh orangtua dan leluhur mereka terdahulu.

Tabel 2 Hubungan modal sosial pendidikan pekerja sektor informal dengan kesejahteraan

\begin{tabular}{|c|c|c|c|c|c|c|c|c|}
\hline \multirow{3}{*}{$\begin{array}{l}\text { Modal } \\
\text { sosial } \\
\text { pendidikan } \\
\text { sektor } \\
\text { informal }\end{array}$} & \multicolumn{6}{|c|}{ Kesejahteraan } & \multicolumn{2}{|c|}{ Total } \\
\hline & \multicolumn{2}{|c|}{ Rendah } & \multicolumn{2}{|c|}{ Sedang } & \multicolumn{2}{|c|}{ Tinggi } & & \\
\hline & $\mathbf{n}$ & $\%$ & $\mathbf{n}$ & $\%$ & $\mathbf{n}$ & $\%$ & n & $\%$ \\
\hline Rendah & 4 & 100 & 0 & 0 & 0 & 0 & 4 & 100 \\
\hline Sedang & 0 & 0 & 25 & 100 & 0 & 0 & 25 & 100 \\
\hline Tinggi & 0 & 0 & 0 & 0 & 1 & 100 & 1 & 100 \\
\hline Total & 4 & 13.3 & 25 & 83.3 & 1 & 3.3 & 30 & 100 \\
\hline
\end{tabular}

\section{SIMPULAN DAN SARAN}

\section{Simpulan}

Hubungan modal sosial pengusaha sektor informal terhadap kesejahteraan. Hasil tersebut menunjukkan hubungan yang kuat namun besifat negatif antara kedua variabel dan hasil uji menunjukkan hipotesis diterima yaitu terdapat hubungan antara modal sosial pekerja sektor informal dengan kesejahteraan. Hal tersebut karena kepercayaan, jaringan, dan norma sosial para pedagang di Jl. Dewi Sartika cukup erat antara satu sama lain, akan tetapi pada urusan pendapatan para pedagang di Jl. Dewi Sartika lebih memilih untuk mengolahnya masingmasing.

Hubungan modal sosial migrasi pengusaha sektor informal terhadap kesejahteraan. Hasil tersebut menunjukkan hubungan yang kuat, bersifat positif antara kedua variabel dan hasil uji menunjukkan hipotesis diterima yaitu terdapat hubungan antara modal sosial migrasi pengusaha sektor informal dengan kesejahteraan. Hal tersebut disebabkan karena pedagang di Jl. Dewi Sartika lebih memilih untuk mengubah nasib di kota lain, mereka yakin dan percaya bahwa mencari kehidupan di kota lain lebih menjamin dari pada di tempat tanah kelahiran merka.

Hubungan modal sosial pendidikan pengusaha sektor informal terhadap kesejahteraan. Hasil tersebut menunjukkan hubungan yang kuat, besifat positif antara kedua variabel dan hasil uji menunjukkan hipotesis diterima yaitu terdapat hubungan antara modal sosial pendidikan pengusaha sektor informal dengan kesejahteraan. Hal tersebut dikarenkan para pedagang di $\mathrm{Jl}$. Dewi Sartika mengetahui jenjang pendidikan yang sesuai untuk berdagang, bertingkahlaku sesuai dengan apa yang telah didapat sewaktu masih menuntut ilmu, lalu kemudian diaplikasikan saat berdagang

\section{Saran}

Hasil hubungan antara modal sosial pengusaha sektor informal terhadap kesejahteraan menghasilkan hubungan negatif, karena kepercayaan, jaringan, dan norma sosial antara pedagang sangat baik akan tetapi untuk masalah pendapatan dan pengeluaran mereka lebih memilih untuk mengurusnya masing-masing, akan tetapi alangkah lebih baik jika para pedagang membuat sebuah suatu tempat menabung pada salah satu pedagang yang menjadi penanggung jawab pemegang uang, yang kemudian dikumpulkan setiap bulan agar pedagang dapat menabung, sehingga pendapatan juga dapat diolah bersama-sama untuk kesejahteraan bersama.

Sebagian besar pedagang di Jl. Dewi Sartika merupakan seorang pendatang, yang bermaksud untuk mencari rezeki dengan tujuan untuk sejahtera, sehingga mereka meninggalkan kampung halaman mereka demi mendapatkan hidup yang lebih baik. akan tetapi alangkah lebih baik jika para pedagang juga membangun usaha di kampung halaman mereka agar mereka mendapatkan pendapatan yang berlipat ganda, sehingga mereka akan lebih sejahtera. 
Rata-rata jenjang pendidikan pengusaha sektor informal di Jl. Dewi Sartika adalah SMP dan tertinggi adalah SMA, belum ada yang sampai jenjang S1. Para pedagang mengerti jika mereka memiliki pendidikan yang tinggi mereka akan mendapatkan kesejahteraan yang lebih baik dari sekarang, alangkah lebih baik jika para pedagang melanjutkan pendidikan yang lebih tinggi demi menghindari kesalahan dalam bersikap, bertingkah laku, bahkan ilmu yang di dapat dari jenjang pendidikan yang tinggi dapat dimanfaatkan untuk berdagang, sehingga mereka dapat lebih sejahtera.

\section{DAFTAR PUSTAKA}

[BKKBN] Badan Kependudukan dan Keluarga Berencana Nasional. 2007. Indikator Kesejahteraan. Jakarta (ID) : BKKBN.

[BPPN] Badan Perencanaan Pembangunan Nasional. 2009. Peran Sektor Informal sebagai Katup Pengaman Masalah Ketenagakerjaan. Jakarta [ID]. [Internet]. [diunduh tanggal 20 Desember 2015]. Dapat diunduh pada : https://bappenas.go.id/index.php/download_fil e/view/7716/1326/kajian evaluasi pembangunan sektoral bppn 2009 tentang sektor informal

[BPS] Badan Pusat Statistik. 2016. Indikator Kesejahteraan. Jakarta (ID) : BPS

[ILO] International Labour Organization. 2014. Ekonomi Informal di Indonesia : Ukuran, Komposisi, dan Evolusi. Jakarta [ID]. [Internet].[diunduh tanggal 27 Agustus 2015]. Dapat diunduh pada: http://www.ilo.org/wcmsp5/gro ups/public/--asia/---ro-bangkok/---ilo

jakarta/documents/publication/wcms 145402.pdf

Abidin D. 2010. Modal Sosial dan Dinamika Usaha Mikro Kecil. Jurnal Sosiologi Masyarakat. [Internet]. [diunduh tanggal 01 Januari 2017]. Vol. 15,No 1 ISSN: 0852-8489. Dapat diunduh pada : http://journal.ui.ac.id/ index.php/ jsm/ article/ viewFile/ 3708/2950

Ahmadi, Uhbiyati. 2007. Strategi Penanganan Pedagang Kaki Lima Di Kota Administrasi Jakarta Utara. Tesis, Universitas Indonesia. Depok.

Alma. 2001. Modal Sosial dan Reduksi Kemiskinan Nelayan di Propinsi Sumatera Utara. [diunduh tanggal 01 Januari 2017] Dapat diunduh pada http://lontar.ui.ac.id/file?file=digital/119247T\%2025230-Ingatan\%20yangDaftar\%20pustaka.pdf
Aruabti R. 2016. Peran Modal Sosial dalam Mendukung Keberlanjutan Pedagang Kaki Lima Pasar Kebon Kembang Bogor. [Skrpsi]. Bogor (ID) : Institut Pertanian Bogor.

Astriyanto T. 2010. Analisis Lokasi Usaha Sektor Informal Bidang Perdagangan dan Jasa di Lingkungan Kmapus Universitas Negeri Semarang Desa Sekaran Kecamatan Gunungpati Kota Semarang. [Skripsi]. Semarang (ID) : Universitas Negeri Semarang.

Benjamin. 2013. Peran Pedagang Kaki Lima dalam Pengolahan Limbah sebagai Upaya Pengendalian Pencemaran Lingkungan di Kawasan Malioboro Kota Yogyakarta. [Internet]. [diunduh pada tanggal 31 September 2015 Pukul 15.00 WIB]. Dapat diunduh pada http://ejournal.uajy.ac.id/4585/1/JURNAL\%20 SKRIPSI.pdf

Bourdieu. 1986. Outline of a Theory of Practice. Cambridge. [Internet]. [diunduh tanggal 01 Januari 2017] Dapat diunduh pada http://lontar.ui.ac.id/file?file=digital/119247T\%2025230-Ingatan\%20yangDaftar\%20pustaka.pdf

Cahyono, Adhiatma. 2012. Peran Modal Sosial Dalam Peningkatan Kesejahteraan Masyarakat Petani Tembakau di Kabupaten Wonosobo. [Internet]. [diunduh 20 Februari 2017]. Vol 15 No. $1: 1-16$. Dapat diunduh di : http://jurnal.unissula.ac.id/ index.php/ cbam/ article/ view/128

Coleman. J.S. 1988. Foundations of Social Theory. [Internet]. [diunduh tanggal 01 Januari 2017] Dapat diunduh pada http://repository.usu.ac.id/bitstream/handle/12 3456789/23317/Reference.pdf;sequence $=2$

Djayastra dan Russicaria.2014. Analisis Faktor Fakator yang Mempengaruhi Pendapatan Kepala Rumah Tangga Miskin pada Sektor Informal di Kecamatan Abiansemal Kabupaten Bandung. E-Jurnal EP Unud. [Internet] [diunduh tanggal 01 Januari 2017] Vol.3, No 4: 134-144 ISSN:2303-0178. Dapat diunduh pada http://ojs.unud.ac.id/index.php/eep/article/vie w/8144/6480

Fahrudin, A. 2012. Pengantar Kesejahteraan Sosial. Atif N, editor. Bandung (ID): PT Refika Aditama.

Field J. 2003. Modal Sosial. Nurhadi, penerjemah; Muzir I; editor. Yogyakarta (ID): Penerbit Kreasi Wacana. Terjemahan dari : Social Capital. Routledge. 
Fuad. 2005. Studi Profil Pekerja Di Sektor Informal Dan Arah Kebijakan Ke Depan. Direktorat Ketenagakerjaan Dan Analisis Ekonomi, Jakarta.

Fukuyama. 2009. Social Capital and Civil Society.The Institute of Publi Policy, George Mason University. [Internet]. [diunduh tanggal 01 Januari 2017]. Dapat diunduh pada : http://r.search.yahoo.com/ ylt=AwrxhSl6grpZ eAkAI0f3RQx.; ylu=X3oDMTEydmhsY2J1B HNlYwNzcgRwb3MDNARjb2xvA3NnMwR 2dGlkA0I0MzcxXzE-

$/ \mathrm{RV}=2 / \mathrm{RE}=1505424122 / \mathrm{RO}=10 / \mathrm{RU}=\mathrm{http} \% 3 \mathrm{a}$ $\% 2 \mathrm{f} \% 2$ fetd.repository.ugm.ac.id $\% 2$ findex.php $\% 3 \mathrm{fmod} \% 3$ ddownload $\% 26 \mathrm{sub} \% 3 \mathrm{dDownload}$ File $\% 26$ act $\% 3$ dview $\% 26$ typ $\% 3$ dhtml $\% 26$ id $\%$ 3d77917\%26ftyp $\% 3$ dpotongan $\% 26$ potongan $\% 3 d S 2-2015-321774-$

Gilbert. Josef. G. 1996. The Social Virtue and The Creation of Properity. [Internet]. [diunduh tanggal 01 Januari 2017]. Dapat diunduh pada

http://r.search.yahoo.com/_ylt=AwrxhSl6grpZ eAkAI0f3RQx.; ylu=X3oDMTEydmhsY2J1B HN1YwNzcgRwb3MDNARjb2xvA3NnMwR 2dGlkA0I0MzcxXzE-

Gould, Prothero. 1994. A clasical theory of The Informal Sector. Journal The Manchaster School Vol LXII no 1, Hal 81 - 96. Cambridge. USA.

Hart. 1973. Does Social Capital Help the Poor?: A Synthesis of Findings from the Local Level Institutions Studies in Bolivia, Burkina Faso and Indonesia. [Internet]. [diunduh tanggal 01 Januari 2017]. Dapat diunduh pada : http://r.search.yahoo.com/_ylt=AwrxhSloHbtZ ZiEAkBD3RQx.; ylu=X3oDMTEyOXAzdm0 1BHNlYwNzcgRwb3MDMQRjb2xvA3NnM wR2dGlkA0I0MzcxXzEbibliography.pdf/RK $=1 / \mathrm{RS}=$ wApjltv5SMc7Kbp847lqN6ntcNU

Harsono. 2014. Social Capital and Sustainable Rural Development: Characteristics and Functions of Labor Institutions in Rural Java. [Internet]. [diunduh tanggal 01 Januari 2017]. Dapat diunduh pada

http://r.search.yahoo.com/ ylt=AwrxhSl6grpZ eAkAI0f3RQx.; ylu=X3oDMTEydmhsY2J1B HN1YwNzcgRwb3MDNARjb2xvA3NnMwR 2dGlkA0I0MzcxXzE-

$/ \mathrm{RV}=2 / \mathrm{RE}=1505424122 / \mathrm{RO}=10 / \mathrm{RU}=\mathrm{http} \% 3 \mathrm{a}$

$\% 2 \mathrm{f} \% 2$ fetd.repository.ugm.ac.id $\% 2$ findex.php

$\% 3 \mathrm{fmod} \% 3$ ddownload $\% 26 \mathrm{sub} \% 3 \mathrm{dDownload}$

File $\% 26$ act $\% 3$ dview $\% 26$ typ $\% 3$ dhtml $\% 26$ id $\%$ 3d77917\%26ftyp $\% 3$ dpotongan $\% 26$ potongan $\% 3 \mathrm{dS} 2-2015-321774-$
Harahap. Sri. H. 1998. Peran Modal Sosial Dalam Mendorong Sektor Pendidikan Dan Pengembangan Wilayah Di Kabupaten Samosir. [tesis]. Medan (ID). Sekolah Pascasarjana Universitas Sumatera Utara Medan

Handionoto. 1988. Modal Sosial dalam Pengelolaan Tambak : Studi Kasus pada Komunitas Petambak di Desa Muara Pantuan Kecamatan Anggana Kabupaten Kutai Kartanegara [tesis]. Bogor (ID). Sekolah Pascasarjana Institut Pertanian Bogor

Handayani N. 2007. Modal Sosial dan Keberlangsungan Usaha. [Skripsi]. Surakarta (ID) : Universitas Sebelas Maret.

Hasbullah. J. 2006. Sosial Capital: Menuju Keunggulan Budaya Manusia Indonesia. [Tesis]. Medan (ID). Universitas Sumatera Utara Medan

Indartini M. 2009. Analisis Variabel yang Berpengaruh terhadap Tingkat Pendapatan Pedagang Makanan dan Minuman Kaki Lima di Alon-Alon Kota Madiun. [Internet]. [diunduh tanggal 01 Januari 2017]. Vol. 10, No 1 : 66-76. Dapat diunduh pada: http://www.unmermadiun.ac.id/repository jur nal_penelitian/Jurnal\%20Sosial/Jurnal\%20Sos ial\%202009/Maret/MINTARTI\%20INDARIN I.pdf

Indonesia :Tren Sosial dan Ketenagakerjaan Agustus 2014.[Internet]. [diunduh tanggal 01 Januari 2017]. Dapat diunduh pada http://www.ilo.org/wcmsp5/groups/public/--asia/---ro-bangkok/---

ilojakarta/documents/publication/wcms 32987 $0 . \mathrm{pdf}$

Kholis MR. 2006. Pemberdayaan Usaha Sektor Informal di Kelurahan Campaka Kecamatan Andir Kota Bandung Provinsi Jawa Barat. [Thesis]. [Internet]. [diunduh tanggal 01 Januari 2017]. Dapat diunduh pada : http://repository.ipb.ac.id/ bitstream/ handle/ 123456789/9743/2006mrk.pdf?sequence $=2$

Kohar A. 2016. Peran Modal Sosial Dalam Pengembangan Profesionalisme Guru Pendidikan Agama Islam di Kabupaten Bantul. [Skripsi]. Yogyakarta (ID) : Universitas Islam Negeri Sunan Kalijaga.

Lawang RMZ. 2005. Kapital Sosial dalam Perspektif Sosiologik suatu Pengantar. [Internet]. [diunduh tanggal 01 Januari 2017]. Dapat diunduh pada http://r.search.yahoo.com/_ylt=AwrxhS16grpZ eAkAI0f3RQx.; ylu=X3oDMTEydmhsY2J1B HNlYwNzcgRwb3MDNARjb2xvA3NnMwR 
2dGlkA0I0MzcxXzE-

$/ \mathrm{RV}=2 / \mathrm{RE}=1505424122 / \mathrm{RO}=10 / \mathrm{RU}=\mathrm{http} \% 3 \mathrm{a}$

$\% 2 \mathrm{f} \% 2$ fetd.repository.ugm.ac.id $\% 2$ findex.php

$\% 3$ fmod $\% 3$ ddownload $\% 26$ sub\%3dDownload

File\%26act $\% 3$ dview $\% 26$ typ $\% 3 \mathrm{dhtml} \% 26 \mathrm{id} \%$

3d77917\%26ftyp\%3dpotongan\%26potongan

\%3dS2-2015-321774-

Lembaga Penelitian UNPAD. 2008. Pemetaan dan

Pemanfaatan Modal Sosial dalam

Penanggulangan Kemiskinan di Jawa Barat.

[Internet]. [diunduh tanggal 01 Januari 2017].

Dapat diunduh pada :http://

pustaka.unpad.ac.id/ wpcontent/ uploads/

2010/ 06/

pemetaan_dan_pemanfaatan_modal_sosial.pdf

Manihuruk ML. 2013. Strategi Bertahan Pelaku

Sektor Informal: Peranan Modal Sosial

Migran Pedagang Kaki Lima di Sekitar Kebun

Raya Bogor. [Internet]. [diunduh tanggal 01

Januari 2017]. Dapat diunduh pada: http:// repository.ipb.ac.id// bitstream/ handle/123456789/63155/I13mlb.pdf?sequenc $\underline{\mathrm{e}=1}$

Martin. 2006, "Labour Market Adjustment in the Time of Krismon: Changes in Employment Structure in Indonesia,1997-98", Singapore Journal of Tropical Geography, Vol.21, No.3, pp.316-335

Mashudi R. 2014. Strategi Penataan Pedagang Kaki Lima di Jalan Dewi Sartika Kota Bogor. [Skripsi]. Bogor (ID) : Institut Pertanian Bogor

Maziyah . 2014. Peran Modal Sosial terhadap Eksistensi Pasar Tradsional (Studi Kasus di Pasar Besar Malang ). Jurnal Ilmiah. [Internet ]. [diunduh tanggal 01 Januari 2017]. Dapat diunduh pada

http://jimfeb.ub.ac.id/index.php/jimfeb/article/ view/980

Magdalena. 1991. Ensiklopedi Ekonomi, Bisnis, Manajemen, Delta Pamungkas, Jakarta

Putnam Robert D. 1995. Bowling Alone: America's Declining Social Capital. Jurnal [Internet]. [diunduh tanggal 4 April 2016 pukul 07.38]. Vol 6 No 1. Dapat diunduh dari http://archive.realtor.org/sites/default/files/Bo wlingAlone.pdf 
Harahap \& Agusta / Jurnal Sains Komunikasi dan Pengembangan Masyarakat 2(2):207-222 